\title{
Media społecznościowe TVP Sport jako przykład innowacyjnego zarządzania treściami sportowymi
}

https://doi.org/10.25312/2391-5129.30/2020_02msz

\begin{abstract}
W artykule przedstawiono problematykę zarządzania treściami sportowymi w mediach społecznościowych. Poruszono kwestie oddzielnych strategii na poszczególnych polach eksploatacji oraz udowodniono, że innowacyjne zarządzanie jest możliwe, ale wymaga indywidualnego podejścia oraz odejścia od „strategii cyfrowej”. Jeszcze niedawno mówiło się o „strategii cyfrowej”. Dzisiaj można stwierdzić z pewnością, że tych strategii musi być kilka. Telewizja linearna nadal przyciąga największe zainteresowanie widzów i generuje rekordowe oglądalności, chociaż malejące $z$ roku na rok. Posiadanie serwisu internetowego jest kluczowe w świecie cyfrowym. Potrzebne są jednak zupełnie różne, ale koherentne strategie w mediach społecznościowych: na YouTubie - dedykowane formaty wideo oraz influencerzy, na Facebooku - tworzenie interesujących postów wymuszających zaangażowanie użytkownika oraz promocja płatnymi postami, na Twitterze - interakcja i szybkość reakcji, ale w skondensowanej formie, na Instagramie zaś materiały zakulisowe i zdjęcia. Artykuł pokazuje, jak zarządzać poszczególnymi kanałami w mediach społecznościowych, daje odpowiedź na pytanie, czy innowacyjne zarządzanie jest możliwe w wirtualnym świecie, namawia do rezygnacji ze standardowej „strategii cyfrowej”.
\end{abstract}

Słowa kluczowe: media społecznościowe, Facebook, YouTube, Twitter, Instagram, TVP Sport, telewizja, internet

* Mgr Marek Szkolnikowski - magister Lingwistyki Stosowanej na Uniwersytecie Warszawskim, absolwent MBA w Szkole Głównej Handlowej, dyrektor TVP Sport, wiceprzewodniczący Komitetu Sportowego Eurowizji, członek Komisji Marketingu Polskiego Komitetu Olimpijskiego, wykładowca, dziennikarz, ekspert do spraw mediów, posiadacz dwóch najwyższych certyfikatów językowych z niemieckiego i angielskiego, beneficjent wielu międzynarodowych stypendiów, m.in. Komisji Europejskiej, Instytutu Austriackiego, Fundacji Hrabiny Marion Doenhoff. 


\section{Wstęp}

Za podstawowy cel artykułu przyjęto próbę przedstawienia sposobu zarządzania treściami sportowymi w mediach społecznościowych oraz udowodnienia, że skuteczne zarządzanie poszczególnymi kanałami komunikacyjnymi wymaga kilku odmiennych substrategii w ramach jednej strategii głównej. Cel zostanie osiągnięty poprzez pokazanie różnych platform zarządzanych przez redakcję interaktywną TVP Sport YouTube, Facebook, Twitter oraz Instagram. Niniejszy artykuł ma odpowiedzieć na pytanie, czy jest możliwa jedna „cyfrowa strategia” w mediach społecznościowych, a postawiona hipoteza zostanie udowodniona w treści artykułu.

W czasach coraz szybszej konsumpcji mediów coraz ważniejsze staje się dotarcie do odbiorców nie tylko poprzez tradycyjną telewizję linearną, ale przede wszystkim za pośrednictwem internetu, a w szczególności aplikacji mobilnych oraz mediów społecznościowych. Według Słownika języka polskiego media społecznościowe to „technologie internetowe i mobilne, umożliwiające kontakt pomiędzy użytkownikami poprzez wymianę informacji, opinii i wiedzy". Dla nowoczesnej telewizji, która chce walczyć o młodego widza, kluczowa jest synergia mediów i przesunięcie akcentów z tradycyjnego myślenia o mediach na bardziej innowacyjne. TVP Sport to kanał naziemnej telewizji cyfrowej dostępny bez żadnych dodatkowych opłat w każdym polskim domu. To sportowy kanał Telewizji Polskiej i lider rynku w grupie kanałów sportowych.

Tabela 1. Oglądalność kanałów sportowych w 2019 roku

\begin{tabular}{|c|c|c|c|}
\hline Wirtualnemedia.pl & \multicolumn{2}{|c|}{ Wszyscy 4+ } & \multirow{2}{*}{ Dynamika } \\
\hline \multirow{2}{*}{ Stacja } & 2018 & 2019 & \\
\hline & SHR \% & SHR \% & $\%$ \\
\hline TVP Sport & 0,968 & 1,247 & 28,82 \\
\hline Polsat Sport & 0,475 & 0,537 & 13,05 \\
\hline Eurosport 1 & 0,535 & 0,502 & $-6,17$ \\
\hline Eleven Sports 1 & 0,087 & 0,158 & 81,61 \\
\hline Eurosport 2 & 0,149 & 0,131 & $-12,08$ \\
\hline Canal+ Sport & 0,120 & 0,118 & $-1,67$ \\
\hline Polsat Sport Extra & 0,099 & 0,114 & 15,15 \\
\hline Extreme Sports & 0,073 & 0,076 & 4,11 \\
\hline nSport+ & 0,097 & 0,072 & $-25,77$ \\
\hline Polsat Sport Fight & 0,064 & 0,070 & 9,38 \\
\hline Polsat Sport News HD & 0,046 & 0,059 & 28,26 \\
\hline Canal+ Sport2 & 0,044 & 0,042 & $-4,55$ \\
\hline Eleven Sports 2 & 0,032 & 0,037 & 15,63 \\
\hline Fightklub & 0,006 & 0,009 & 50,00 \\
\hline Canal+ Sport3 & - & 0,006 & - \\
\hline
\end{tabular}




\begin{tabular}{|l|c|c|c|}
\hline \multirow{2}{*}{ Wirtualnemedia.pl } & \multicolumn{2}{|c|}{ Wszyscy 4+ } & \multirow{2}{*}{ Dynamika } \\
\hline \multirow{2}{*}{ Stacja } & 2018 & 2019 & $\%$ \\
\cline { 2 - 3 } & SHR $\%$ & SHR $\%$ & 0,00 \\
\hline Motowizja & 0,005 & 0,005 & - \\
\hline Canal+ Sport4 & - & 0,001 & \\
\hline
\end{tabular}

Źródło: Kurdupski, 2020.

TVP Sport to nie tylko największy i najbardziej wpływowy kanał sportowy w Polsce, który poza własną działalnością odpowiada również za całą ofertę sportową w Telewizji Polskiej (TVP1, TVP2, TVP3, TVP Info), ale to też strona internetowa tvpsport.pl oraz redakcja interaktywna, która odpowiada za aplikację mobilną oraz kanały w mediach społecznościowych, których łączna liczba obserwujących wynosi ponad 873 tysiące (stan na 1 marca 2020). Najwięcej użytkowników - 512 tysięcy - śledzi dziś profil TVP Sport na Facebooku. Jeśli chodzi o pozostałe serwisy, to 244 tysiące subskrybentów ma kanał na YouTube, 83 tysiące na Twitterze oraz 34 tysiące na Instagramie.

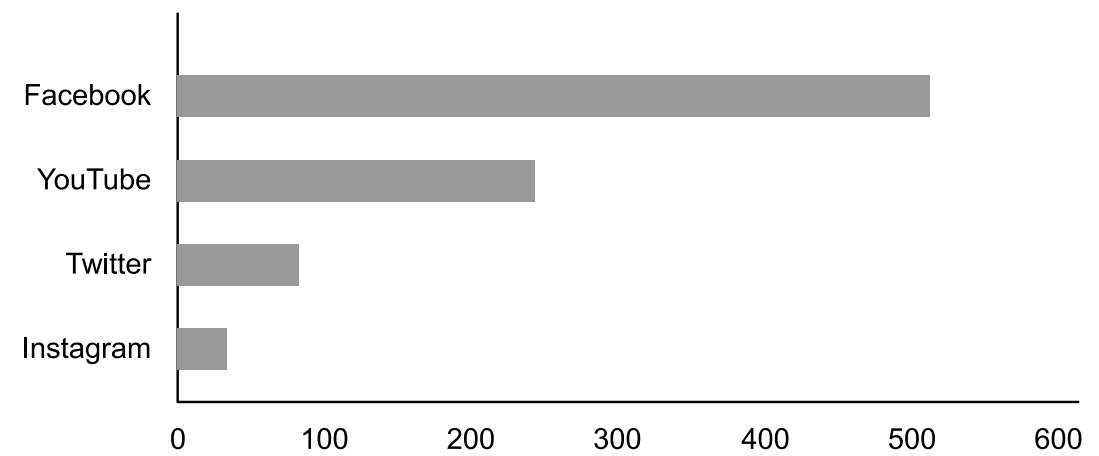

Rysunek 1. Liczba obserwujących poszczególne kanały społecznościowe TVP Sport (w tys.)

Źródło: opracowanie własne.

Zarządzanie mediami społecznościowymi TVP Sport jest z jednej strony komfortowe, ponieważ pozwala korzystać z pracy czołowych dziennikarzy i ekspertów, którzy są na miejscu najważniejszych wydarzeń, oraz - przede wszystkim - z materiałów wideo, fragmentów transmisji, które stacja ma w Polsce na wyłączność. To daje ogromną przewagę nad pozostałymi kanałami. Niemniej jednak należy pamiętać, że podstawowym celem kanałów społecznościowych jest promocja sportu na antenach TVP, co często powoduje konieczność pójścia na kompromis. Idealnie prowadzone social media muszą znaleźć balans pomiędzy tym, co zwiększa ich zasięg, co w danym momencie generuje największe zainteresowanie wśród kibiców, a tym, co najważniejsze z perspektywy TVP Sport.

Na potrzeby niniejszego artykułu dokonano analizy poszczególnych platform internetowych TVP Sport oraz pokazano wielowymiarowość poruszanej tematyki. 
W mediach mówi się od dłuższego czasu o „strategii cyfrowej”, jednak trudno znaleźć definicję, która byłaby w stanie wyjaśnić to zjawisko. Strategii w mediach społecznościowych jest tyle, ile poszczególnych platform, gdyż każda z nich ma swoją specyfikę i na każdej z nich komunikacja z odbiorcą wygląda diametralnie różnie. Cel niniejszego artykułu to próba pokazania, w jaki sposób innowacyjne podejście do poszczególnych grup odbiorców może przełożyć się na zwiększenie zasięgów oraz skuteczną komunikację na różnych polach eksploatacji.

\section{Facebook}

Facebook to najbardziej znane medium społecznościowe na świecie. Szacuje się, że ma ponad 2,5 miliarda użytkowników. W Polsce zarejestrowanych jest ponad 18 milionów kont (źródło: whysosocial.com). Serwis powstał w 2004 roku i był przeznaczony dla studentów Harwardu, jednak zainteresowanie było tak ogromne, że po kilku miesiącach rozszerzono zasięg działalności o kolejnych 30 szkół wyższych. I tak oto bez żadnych intencji biznesowych, analizy SWOT i pięciu sił Portera powstała ogromna machina do robienia pieniędzy i dobrowolnego przekazywania swoich zdjęć, lokalizacji, numerów kart kredytowych itd. To również znakomita platforma komunikacyjna, narzędzie umożliwiające interakcję użytkowników oraz doskonałe pole do promocji własnych treści.

Kanał facebookowy TVP Sport to perła w koronie redakcji interaktywnej. Niemniej jednak bez innowacyjnego zarządzania trudno byłoby dotrzeć z poszczególnymi treściami do użytkowników. Na początku 2018 roku Mark Zuckerberg ogłosił zmiany w algorytmie. Facebook postawił na treści, które generują interakcje, komentarze znajomych, zaczął priorytetowo traktować posty, które interesują naszych znajomych. Dlatego też niezbędna była weryfikacja dotychczasowej polityki gospodarowania treściami na tym medium. Do tej pory większość redakcji wstawiało linki do serwisów zewnętrznych, w ten sposób generując polubienia czy udostępnienia, jednocześnie promując swoje strony i „wyprowadzając” użytkowników poza Facebook. Zuckerberg nie zdradził oczywiście wszystkich szczegółów, jednakże pojawiło się wiele opracowań, które miały za zadanie pomóc zarządzać profilami w nowej rzeczywistości. W najbardziej fachowy sposób algorytm na czynniki pierwsze rozłożył Stephen Davies w artykule Decoding the social media algorithms in 2019. The ultimate guide. Wśród treści „przyjaznym” algorytmom znalazły się własne materiały wideo, zdjęcia oraz wejścia na żywo. Powstał specjalny ranking, na bazie którego algorytm wylicza punktację. Im więcej interakcji użytkownika z naszymi postami, tym lepiej. Po drugiej stronie barykady znalazły się linki zewnętrzne, „klikbajty”, prośby o polubienia czy udostępnienia. Taka minirewolucja zmusiła redakcję TVP Sport do przedefiniowania prowadzenia oficjalnego kanału na Facebooku.

Oglądalność kanału facebookowego badana jest od marca 2017 roku, kiedy dokonano fuzji wszystkich sportowych kanałów TVP. Wtedy połączony profil miał 
411 tysięcy obserwujących. Od tamtego czasu liczba użytkowników zwiększyła się o ponad 100 tysięcy! Warto zauważyć, że wzrosty udało się osiągnąć, nie korzystając z płatnych kampanii promujących posty. Redakcja zaczęła z nich korzystać dopiero pod koniec 2019 roku. Na początku 2020 roku aż 23 posty dotarły do więcej niż $1 \mathrm{mi}$ liona użytkowników portalu, a najlepszy z nich - komentarz Piotra Żyły po zwycięstwie Dawida Kubackiego w 68. Turnieju Czterech Skoczni do blisko 5,2 milionów użytkowników.

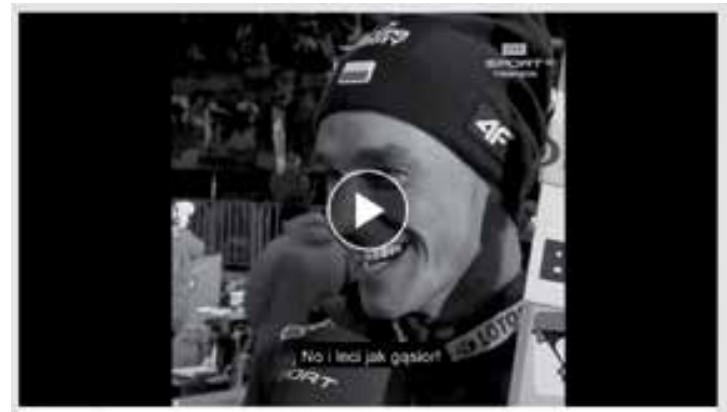

[5.57. TVP Sport: Piotr Zyta o Dawidzie Kubackim: psyehika Pokemona I lot gasiona.

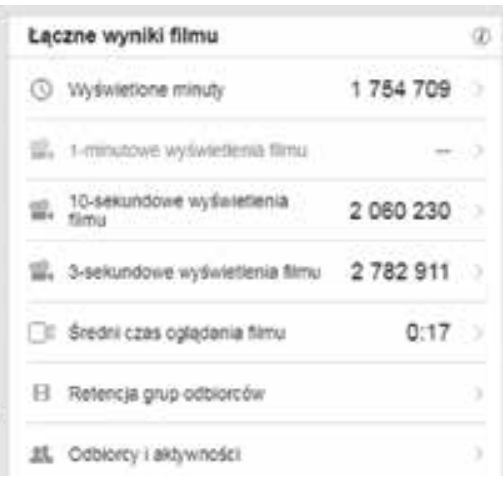

Rysunek 2. Piotr Żyła o Dawidzie Kubackim - najlepiej wyświetlany film na Facebooku TVP Sport

Źródło: TVP Sport.

Aby rozwijać kanały na Facebooku, niezbędna jest więc płatna promocja. „Wymusza" ją poniekąd sama platforma, która siłą rzeczy nie działa charytatywnie. Płatna promocja, primo, pozwala uniknąć ,ścinania” zasięgów przez Facebooka oraz, secundo, daje możliwość dotarcia do zdecydowanie większej liczby użytkowników. Przykładowe „dopalenie” posta kwotą 1000 zł powoduje zwiększenie zasięgu o 325 tysięcy użytkowników! Szczególnie ważne jest to przy budowaniu większych zasięgów dla mniej popularnych transmisji, niszowych dyscyplin, sportowego CSR-u oraz publikacji w ramach zobowiązań partnerskich. Warto zaznaczyć, że wpis, który wygeneruje duży zasięg czy osiągnie status wiralowego, wpływa pozytywnie na zasięg kolejnych publikowanych na danym kanale. I przeciwnie - kilka mniej udanych wpisów powoduje negatywną reakcję algorytmu Facebooka.

\section{YouTube}

YouTube powstał w 2005 roku. To serwis internetowy, który umożliwia umieszczanie filmów. Polska wersja serwisu została uruchomiona dwa lata później. Według statystyk dzisiaj użytkownicy oglądają ponad miliard godzin filmów dziennie (źródło: googleblog.com). W Polsce liczbę użytkowników szacuje się na ponad 20 milionów. Przez lata serwis ewoluował i stał się ważnym elementem świata popkultury, tworząc 
nowe i niezbadane dotąd pola eksploatacji doskonale eksplorowane przez celebrytów naszych czasów tzw. youtuberów. Serwis stał się miejscem, w którym można zarabiać niebagatelne kwoty. Na kontach najbardziej popularnych trendsetterów co roku pojawia się po kilkadziesiąt milionów dolarów (źródło: zarobkowyninja.pl).

YouTube TVP Sport w ciągu ostatnich dwóch lat zaliczył najbardziej spektakularny wzrost. To był najbardziej niedoceniany i zaniedbywany serwis w portfolio kanału sportowego Telewizji Polskiej. Nigdy nie było pomysłu na wykorzystanie osobowości telewizyjnych na YouTubie. Internet i telewizja linearna to dwa oddzielne światy i przez wiele lat tradycyjne media na tym polu przegrywały. Kanał TVP Sport na początku 2018 roku miał zaledwie 65 tysięcy subskrybentów. Dopiero otwarcie się na współpracę z youtuberami pozwoliło na zdobycie odpowiedniego zasięgu. Na początku 2020 roku subskrybentów było już prawie 300 tysięcy! Bardzo dobry efekt przyniosło nawiązanie współpracy z Footrollem (460 tysięcy subskrybentów) podczas Mistrzostw Świata w Rosji. Głównym celem działalności na YouTubie stało się zwiększenie liczby subskrybentów oraz liczby odtworzeń wideo. Nowa strategia zaczęła opierać się na lepszej selekcji materiałów, większej częstotliwości publikacji, lepszym opisywaniu tytułów i zamianie „,randomowych” stopklatek na specjalne grafiki zachęcające do kliknięcia. Między innymi dzięki temu w 2019 roku kanał odnotował prawie 70 milionów odtworzeń materiałów wideo, które wygenerowały przychód w wysokości 40 tysięcy dolarów. W porównaniu do 2018 roku kanał zaliczył wzrost liczby odtworzeń o ponad 10 milionów mimo faktu, że w tym czasie odbywały się piłkarskie mistrzostwa świata oraz igrzyska olimpijskie, czyli imprezy o największym znaczeniu w świecie sportu.

\section{W 2019 roku Twoje filmy uzyskały 69741594 wyświetlenia}

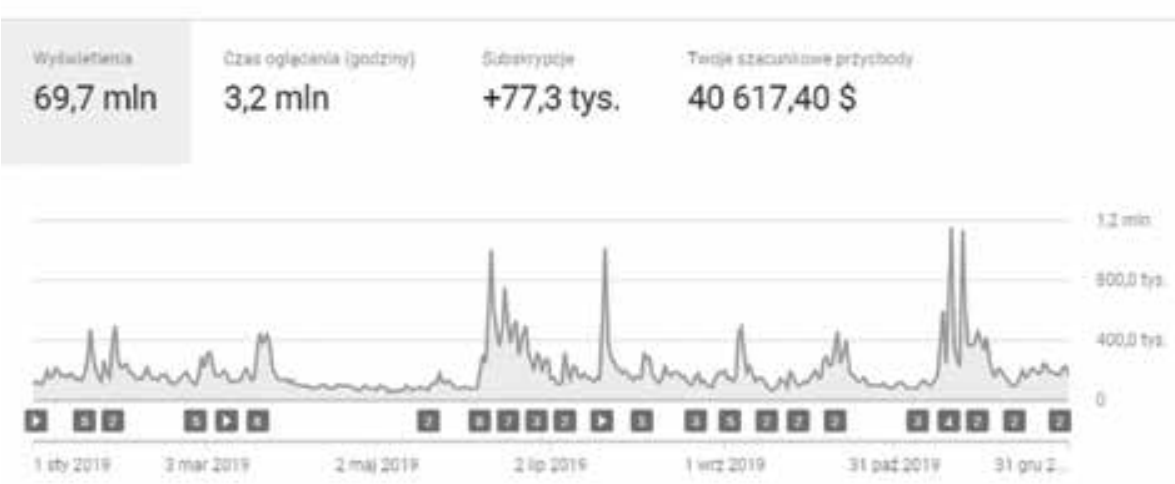

Rysunek 3. Liczba odtworzeń wideo na YouTube TVP Sport w 2019 roku Źródło: YouTube.

Najbardziej popularnym klipem w historii YouTube TVP Sport stał się utwór Koko Euro Spoko zespołu Jarzębina - oficjalna piosenka reprezentacji Polski na 
Euro 2012 - który od momentu publikacji (2 maja 2010 roku) wygenerował już ponad 13,5 miliona odtworzeń.

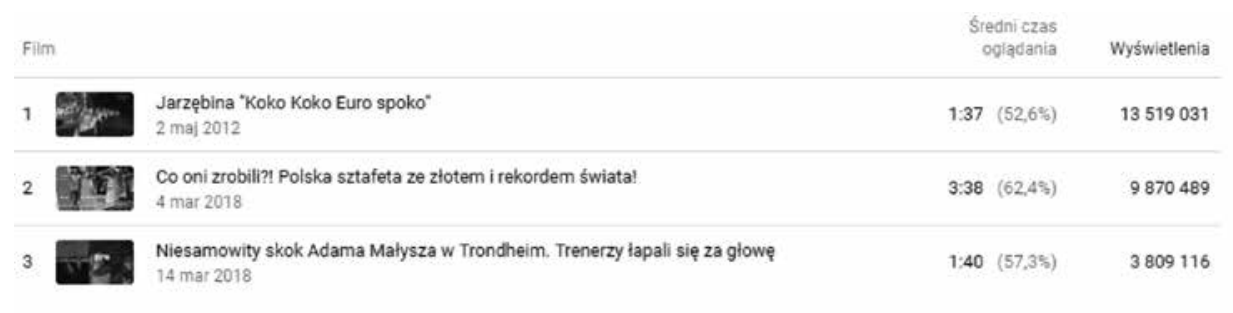

Rysunek 4. Najpopularniejsze materiały wideo w historii YouTube TVP Sport Źródło: YouTube.

Mimo niewątpliwego sukcesu, jakim jest zwiększenie zasięgu i liczby subskrybentów kanału youtube'owego dzięki implementacji nowej strategii, nadal jest to najbardziej rozwojowy kanał. Po pierwsze, liczba użytkowników, która z poziomu YouTube trafia na stronę internetową TVP Sport, jest nadal niezadowalająca. Należy pamiętać, że główną osią strategii TVP Sport jest kanał linearny i strona internetowa. Przykładowo 60 milionów wyświetleń w 2018 roku na YouTube przełożyło się tylko na 105 tysięcy odsłon strony tvpsport.pl. W 2019 roku liczba ta została podwojona, ale nadal jest niesatysfakcjonująca. Po drugie, publikacją treści na YouTube powinien zajmować się osobny redaktor specjalnie do tego przeszkolony, który będzie znał najważniejsze narzędzia serwisu, będzie śledził trendy oraz kreował długofalową strategię. Po trzecie zaś, tak jak na Facebooku, Twitterze czy Instagramie potrzebne są specjalne dedykowane treści. W przypadku YouTube to formaty wideo zdecydowanie dłuższe niż w przypadku pozostałych platform, a jedną z kluczowych dla algorytmu wartości jest czas, jaki użytkownik poświęca na obejrzenie materiału. Ważna jest również regularność publikowania treści oraz atrakcyjna szata graficzna.

\section{Twitter}

Twitter z kolei to serwis udostępniający usługę mikroblogowania, „postowania” krótkich i zwartych informacji - każdy tweet może mieć maksymalnie 280 znaków. Angielskie słowo tweet oznacza ćwierkanie. W języku polskim używany jest czasownik tweetować oznaczający pisać na Twitterze. Platforma powstała w 2006 roku. Fenomen tego serwisu polega na tym, że można obserwować wszystkich użytkowników, wchodzić z nimi w interakcję oraz podawać dalej poszczególne treści. Według stanu z października 2019 roku najwięcej obserwujących ma były prezydent Stanów Zjednoczonych Barack Obama - prawie 110 milionów!

Kanał TVP Sport powstał w 2010 roku, ale największy wzrost zanotował w ciągu ostatnich dwóch lat. Na początku 2018 roku obserwujących było niewiele ponad 
50 tysięcy, dwa lata później to już ponad 80 tysięcy. Twitter to narzędzie przeznaczone przede wszystkim do szybkiego reagowania, śledzenia trendów, informowania o ważnych wydarzeniach. W przypadku kanału sportowego najczęściej są to zmiany w ramówce czy informacje o bieżącej ofercie programowej. Mimo faktu, że algorytm nie jest tak skomplikowany jak w przypadku Facebooka, serwis wymaga indywidualnego podejścia, dużo większej częstotliwości publikacji i przede wszystkim interakcji z użytkownikami. Algorytm pozytywnie reaguje na własne materiały wideo i zdjęcia, ale nie lubi linków zewnętrznych. Ważny jest czas, czyli szybkość publikacji oraz to, czy dany wpis angażuje użytkowników.

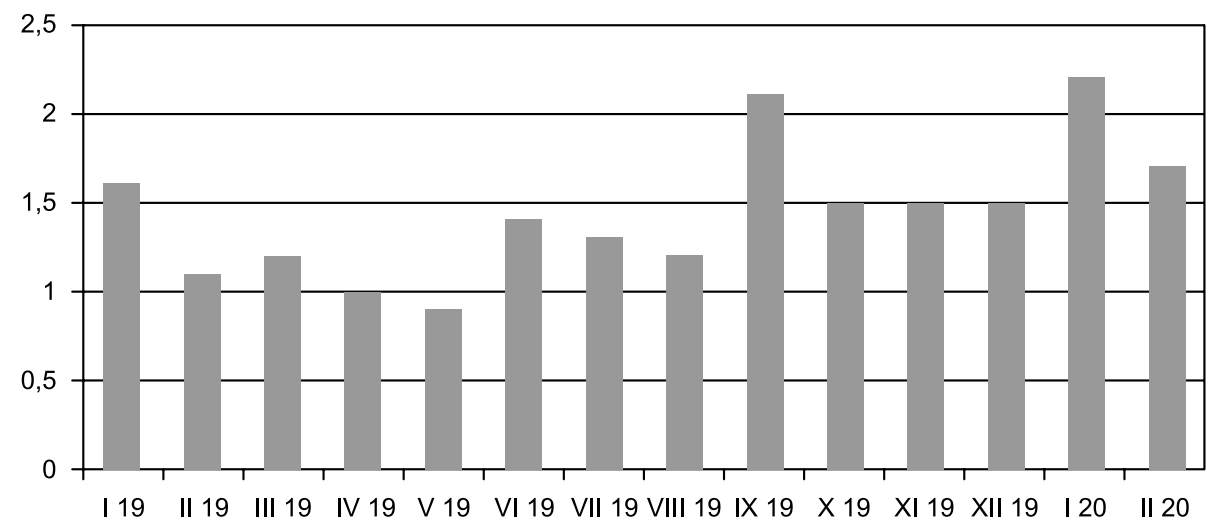

Rysunek 5. Wzrost liczby użytkowników Twittera TVP Sport w poszczególnych miesiącach (w tys.)

Źródło: opracowanie własne.

W przypadku Twittera redakcja TVP Sport stoi przed nie lada wyzwaniem. Mimo wprowadzenia nowych zaleceń odnośnie zarządzania kanałem liczba użytkowników nie zwiększa się tak szybko, jak oczekiwano. W tej chwili to około 1,5 tysiąca użytkowników miesięcznie. Problemem nie jest strategia, ale jej wdrożenie. Nadal brakuje dedykowanych pracowników, co często uniemożliwia błyskawiczne reagowanie czy obsługę na żywo części ważnych wydarzeń. Kuleje również interakcja z użytkownikami, a największym problemem są sami dziennikarze TVP Sport, którzy wciąż za mało aktywnie prowadzą swoje konta. W skrajnych przypadkach nie prowadzą ich wcale. Niechętnie wchodzą też w interakcje z użytkownikami, rzadko promują swoje programy czy materiały, nawet własne... Poza tym redakcja nie wykorzystuje potencjału ich obecności podczas najważniejszych imprez, trwoniąc przewagę TVP Sport nad innymi redakcjami. 


\section{Instagram}

Instagram powstał w 2010 roku. Specyfika tego serwisu jest zupełnie inna niż dwóch poprzednich. Skupia się przede wszystkim na hostingu fotografii oraz krótkich form wideo. W czerwcu 2018 roku liczba użytkowników na całym świecie wyniosła już ponad miliard. Nazwa portalu pochodzi od instant camera oraz telegram. Telewizja Polska aktywnie zaczęła zarządzać kanałem instagramowym dopiero w 2017 roku. W ciągu dwóch lat serwis zanotował procentowo największy wzrost spośród wszystkich mediów społecznościowych. Na początku 2018 roku obserwatorów było zaledwie 1,8 tysięcy. Na początku marca 2020 roku było to już ponad 34 tysiące.

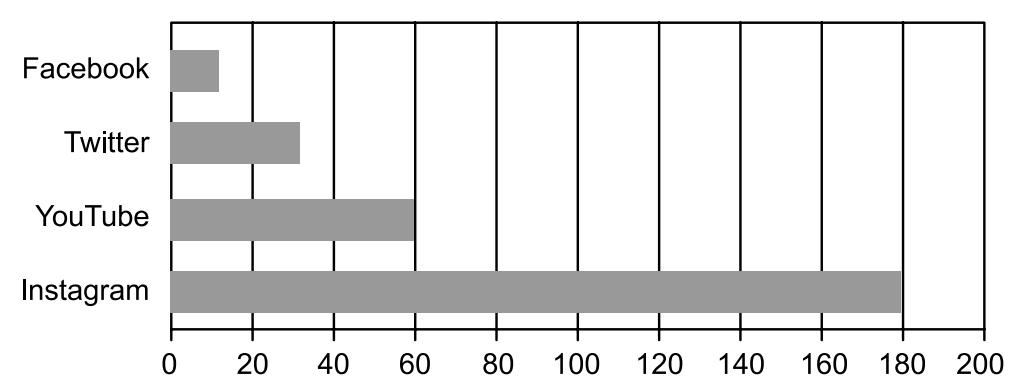

Rysunek 6. Wzrost liczby użytkowników poszczególnych kanałów społecznościowych TVP Sport w ciągu 14 miesięcy - od stycznia 2018 do lutego 2020 roku (procentowo)

Źródło: opracowanie własne.

Po przekroczeniu 10 tysięcy obserwujących Instagram daje możliwość linkowania do serwisów zewnętrznych, z czego korzysta portal tvpsport.pl. Niestety w 2019 roku było to zaledwie 9,1 tysięcy odsłon. Powyższy wykres pokazuje, jak dynamiczny to był wzrost. Wynika on wprost proporcjonalnie z aktywnego zarządzania, ale również zadziałał efekt nowości. Średnio kanałowi przybywa 1,5 tysiąca obserwujących miesięcznie.

O ile pozostałymi kanałami social media można w większości zarządzać stacjonarnie, o tyle zupełnie nie sprawdza się to w przypadku Instagrama. Użytkownicy oczekują zakulisowych materiałów, zdjęć z pierwszego frontu i miejsca akcji. Najbardziej lubianymi materiałami są pokazujące pracę reporterów i komentatorów TVP Sport podczas zawodów sportowych lub bezpośrednio przed. Dlatego też kluczowe jest zaangażowanie osób będących na miejscu wydarzeń. Mimo dużej poprawy w podejściu dziennikarzy TVP Sport do serwisów społecznościowych nadal brakuje zdjęć, materiałów wideo z aren sportowych czy studia telewizyjnego, bez których szybki rozwój kanału jest praktycznie niemożliwy. Podobnie jak w przypadku innych mediów społecznościowych Instagram rządzi się swoim algorytmem, który decyduje o tym, do jak dużej grupy odbiorców docierają posty. Kluczowe są między innymi liczba obserwujących, regularność publikacji, angażowanie użytkowników, 
używanie lokalizacji, hasztagów itd. Tak więc również w tym przypadku potrzebna jest zupełnie inna strategia niż przy każdej pozostałej platformie.

\section{TikTok}

Liczba użytkowników internetu w Polsce to według raportu \#Digital2020 ponad 30 milionów. W 2019 roku liczba ta wzrosła o ponad 2\%. Zdecydowanie szybciej rośnie jednak grono użytkowników mediów społecznościowych. Korzysta z nich 19 milionów Polaków. Największą grupę stanowią osoby w wieku 25-34 lat, a średni czas spędzony w mediach społecznościowych to 2 godziny dziennie.

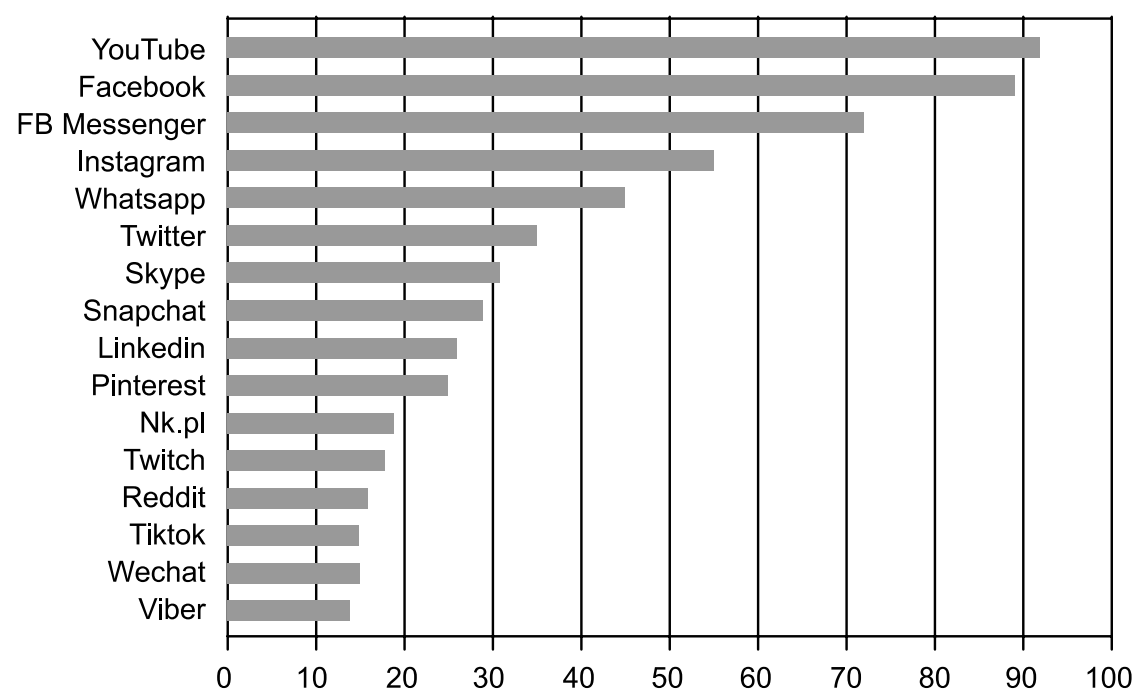

Rysunek 7. Procent użytkowników poszczególnych mediów społecznościowych w Polsce Źródło: raport \#Digital2020 WeAreSocial i Hootsuite.

Media społecznościowe są jak perpetuum mobile, co chwilę powstają nowe serwisy z nowymi funkcjonalnościami. Jednym z nich jest TikTok, który notuje dynamiczny wzrost i błyskawicznie zyskuje nowych użytkowników, również w Polsce. Według raportu \#digital2020 używa go obecnie ponad 15\% ze wszystkich osób korzystających z mediów społecznościowych, czyli prawie 3 miliony użytkowników. Na całym świecie jest ich już około półtora miliarda, a TikTok stał się czwartą najbardziej popularną aplikacją na świecie. Aplikacja działa na bazie efektów, filtrów, utworów muzycznych, pozwala na tworzenie i udostępnianie krótkich filmików. Według badania Open Mobi aż 53\% użytkowników TikToka mieściło się w przedziale wiekowym 11-13 lat. Z aplikacji coraz odważniej korzystają kluby piłkarskie, sportowcy oraz media (m.in. „Newsweek”), jednak cały czas jest to ,terra incognita”. Większe zaangażowanie się w rozwój kanału wymagałoby przeszkolenia i od- 
delegowania do obsługi tej aplikacji dodatkowych osób lub nawiązania współpracy z influencerami. Użytkownicy oczekują dużej kreatywności, poczucia humoru, wykorzystania narzędzi, jakimi dysponuje TikTok, dlatego sama publikacja nawet zabawnych materiałów wideo nie wystarczy. W kontekście dynamicznie rosnącego zainteresowania TikTok staje się cennym narzędziem umożliwiającym dotarcie do potencjalnego widza, szczególnie młodego, z ofertą programową.

\section{Podsumowanie}

Celem niniejszego artykułu była próba pokazania, że nie istnieje coś takiego jak jedna „strategia cyfrowa”. Postawiona hipoteza sugerowała, że potrzeba kilku substrategii, które różnią się od siebie w zależności od pola eksploatacji. Skuteczne i innowacyjne zarządzanie mediami społecznościowymi jest więc możliwe, ale wymaga indywidualnego podejścia oraz odejścia od myślenia ,analogowego”. Mimo zmiany strategii i bardzo dużych wzrostów w cyfrowym świecie wszystko, co innowacyjne w chwili wymyślenia przestaje być innowacją. To jest proces ciągły, który nigdy się nie kończy. Dlatego też w najbliższych miesiącach należy zdecydowanie wzmocnić kanał YouTube, który, jak pokazuje powyższy wykres, jest najbardziej popularnym kanałem społecznościowym w Polsce. Potrzebne są formaty wideo dedykowane stricte kanałowi youtube’owemu, dłuższe formy wideo, szczególnie w kontekście dużych imprez, takich jak mistrzostwa Europy w piłce nożnej czy igrzyska olimpijskie. Konieczne jest również rozważenie stałej współpracy z youtuberami oraz stworzenie semiprofesjonalnego studia do produkcji formatów internetowych. Niezbędna jest także kontynuacja polityki płatnego promowania postów na Facebooku oraz wzmocnienie zespołu obsługującego Twittera, tak żeby była szybsza i lepsza komunikacja z użytkownikami. Kluczowe jest ponadto przekonanie zespołu TVP Sport, że bez zaangażowania największych gwiazd i pracy organicznej tych mniej rozpoznawalnych dziennikarzy walka o użytkownika w sieci będzie przegrana. W dzisiejszych czasach sama telewizja jest dalece niewystarczająca. W poprzedniej dekadzie TVP Sport nie odpowiedział na wyzwania ówczesnego świata, tym razem powinno być inaczej. Pozostaje zacytować Po drugiej stronie Lustra i co tam Alicja znalazła Lewisa Carolla: „Bo widzisz, TUTAJ musisz biec tak szybko, jak tylko potrafisz, żeby zostać w tym samym miejscu. A jak chcesz dostać się w inne miejsce, musisz biec dwa razy szybciej”. 


\section{Bibliografia}

Davies S. (2020), Decoding the social media algorithms in 2020. The ultimate guide. Unwrapping the riddles in a mystery, https://www.stedavies.com/social-media-algorithms-guide/ [dostęp: 12.04.2020].

Kemp S. (2020), Digital 2020: Poland, https://datareportal.com/reports/digital2020-poland [dostęp: 26.04.2020].

Kurdupski M. (2020), TVP Sport liderem oglądalności w 2019 roku, Eleven Sports 1 z największym wzrostem, https://www.wirtualnemedia.pl/artykul/ogladalnosc-kanalow-sportowych-2019-rok-tvp-sport-liderem [dostęp: 4.04.2020].

Pallus P. (2020), Telewizję w 2019 roku oglądaliśmy krócej. Królowat Polsat, ale TVP ma też powód do zadowolenia, https://businessinsider.com.pl/media/tv -radio/ogladalnosc-telewizji-w-2019-roku-dane-nielsena/ffwwf89 [dostęp: 28.04.2020].

Roguski A. (2020), Użytkownicy social media w Polsce i na świecie, https://www. whysosocial.pl/uzytkownicy-social-media-w-polsce-i-na-swiecie/ [dostęp: 8.04.2020].

\section{Summary \\ TVP Sport social media as an example of innovative sport content management}

This article presents the issues of sport content management in social media. The issues of separate strategies in different fields of exploitation are discussed and it is shown that innovative management is possible, but it requires an individual approach and a departure from "the digital strategy". Until recently, there was talk of a (singular) "digital strategy". Today it can be stated with certainty that there must be several of these strategies. Apart from television, which still attracts the greatest interest from viewers and which generates record viewership, (though declining year on year), and a website which is crucial in the digital world, completely different but coherent strategies in social media are needed. YouTube needs dedicated video formats and influencers, on Facebook it is important to create interesting posts that require user involvement and promotion with paid posts, on Twitter, interaction and speed of reaction, but in a condensed form, and behind-the-scenes materials and photos on Instagram. The article shows how to manage individual channels in social media, gives an answer to the question whether innovative management is possible in the virtual world and encourages companies to give up the standard "digital strategy".

Keywords: Social media, Facebook, Youtube, Twitter, Instagram, TVP Sport, television, internet 